TAPROBANICA, ISSN 1800-427X. January, 2015. Vol. 07, No. 01: pp. 56, pl. 22.

(C) Research Center for Climate Change, University of Indonesia, Depok, Indonesia \& Taprobanica Private Limited, Homagama, Sri Lanka www.taprobanica.org

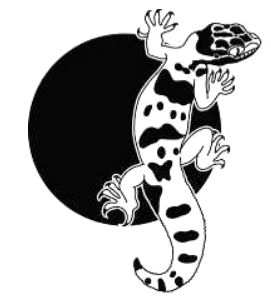

\section{A nocturnal call of the black ibis (Pseudibis papillosa)}

During the night of 12 May 2013, in Udaipur city $\left(24^{\circ} 31^{\prime} 30^{\prime \prime} \mathrm{N} 73^{\circ} 40^{\prime} 38^{\prime \prime} \mathrm{E}\right)$, we heard a harsh sound that could not be associated with any animal. The following morning we observed a pair of black ibis (Pseudibis papillosa) with one juvenile on top of an Azadirachta indica (Meliaceae) tree which was the tallest among all nearby trees. The birds were on a platform-type nest made of small sticks. We heard the same call the following night. While tracking the direction of the sound in the moonlit night, we found that the black ibis was making such a call on the same tree. After two consecutive days of hearing the same strange call we decided to record it and see if the call would recur. We heard the same type of call for the next 13 days. Black ibis made this call between 24:00 $\mathrm{h}$ and 01:30 h each night. During these 13 days, we recorded all calls (of two birds) with the help of a Canon SX40 video camera and later conducted sound analysis to understand the structure of this unusual call. The video file was converted into WAVE audio file using Total Video Converter 3.02 software and analyzed with the help of Raven Pro 1.4 software.

The analysis revealed that the unusual call consisted of series of calls (Fig. 1). A total of 13 calling bouts were recorded. The calls varied from nine to 11 for each call bout with an average of $10 \pm 1$ calls. Mean duration of call bouts was $47.4 \pm 5.41 \mathrm{sec}$. In a call bout, the first and last few calls were of low amplitude. Mean interval between two calls was $4.09 \pm 3.36 \mathrm{sec}$, $(\mathrm{n}=110$; range $=0.3-11.5 \mathrm{sec})$ and it decreased in the last segment of the call bout. The frequency range of one call bout is 9.94-16.00 $\mathrm{kHz}(\mathrm{n}=11)$. The analysis of a single call shows that it has several bands of different timing range $(0.15-0.76 \mathrm{sec})$ and frequencies. These bands are present on 2.0, 3.2, 5.0, 6.6, 8.1, 9.1, $10.2,11.8,13.2$, and $16.0 \mathrm{kHz}$ in the spectrogram (Fig. 2).
This call was very harsh and loud and was possibly an 'alarm' signalto drive away predators. There are two earlier reports on black ibis (Soni, 2008; Soni \& Sharma, 2007), but no records of this unusual night calling.

\section{Acknowledgement}

We thank V. K. Koli for assistance in preparing this manuscript.

\section{Literature cited}

Soni, K. C. and A. N. Sharma, 2007. Role of the Black ibis (Pseudibis papillosa) in crop protection in agriculture fields around Churu city, Rajasthan, India. Flora \& fauna, 13: 371-374.

Soni, K. C., 2008. Study on the population, foraging, roosting and breeding activities of the Black ibis/Red-napped ibis (Pseudibis papillosa) inhabiting the arid zone of Rajasthan. Ph. D. Thesis submitted to M. D. S. University, Ajmer (Rajasthan).

Submitted: 13 Mar. 2014, Accepted: 19 July 2014 Section Editor: Varadharajan Gokula

$$
\text { D. S. Shekhawat }{ }^{1,2} \& \text { C. Bhatnagar }{ }^{1,3}
$$

\footnotetext{
${ }^{1}$ Aquatic Toxicology \& Wildlife Research Laboratory, Department of Zoology, Mohanlal Sukhadia University, Udaipur 313001, Rajasthan, India.

${ }^{2}$ E-mail: sdeependrasingh@yahoo.com ${ }^{3}$ E-mail: bhatnagarchhaya@yahoo.co.in
} 


\section{PLATE 22}

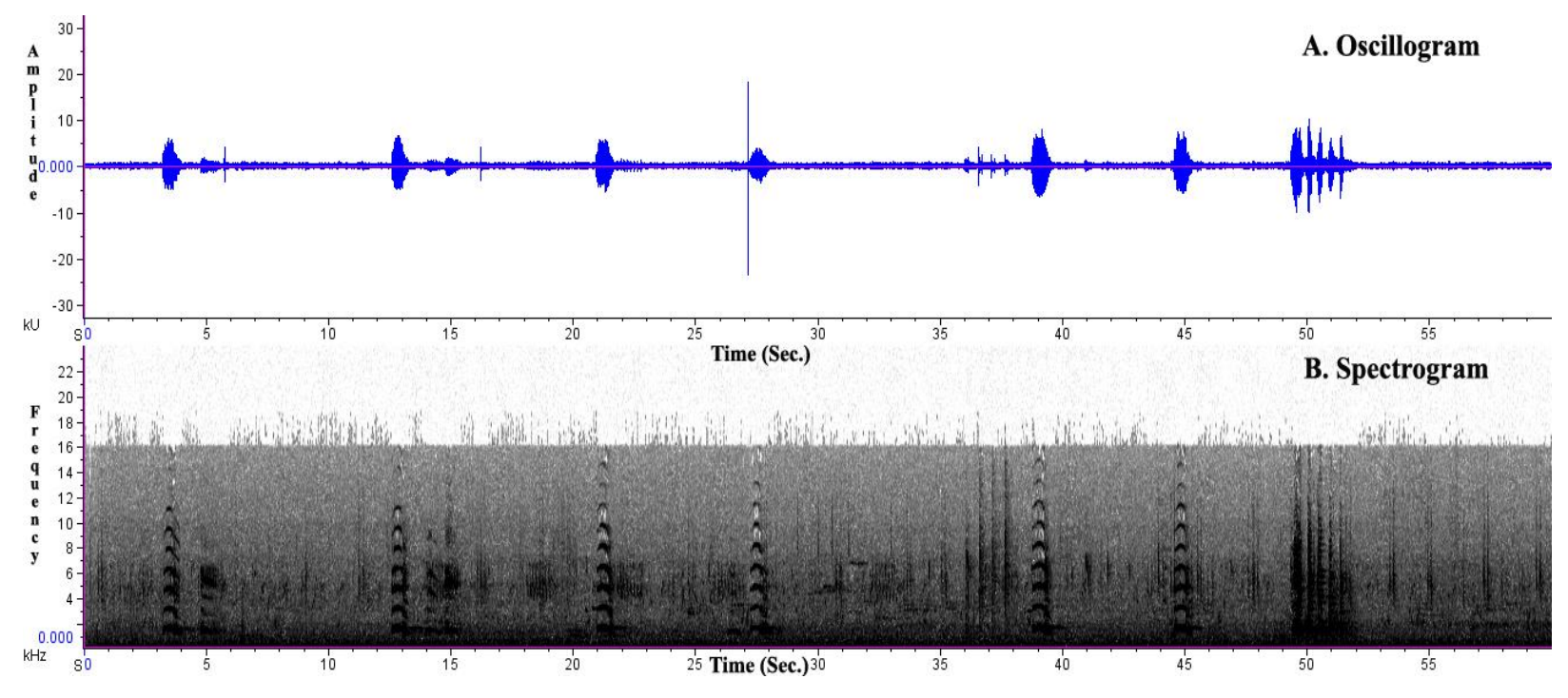

Figure 1: Oscillogram and Spectrogram of one call bout of Black Ibis. Each Dark band shows an individual call of a call bout.

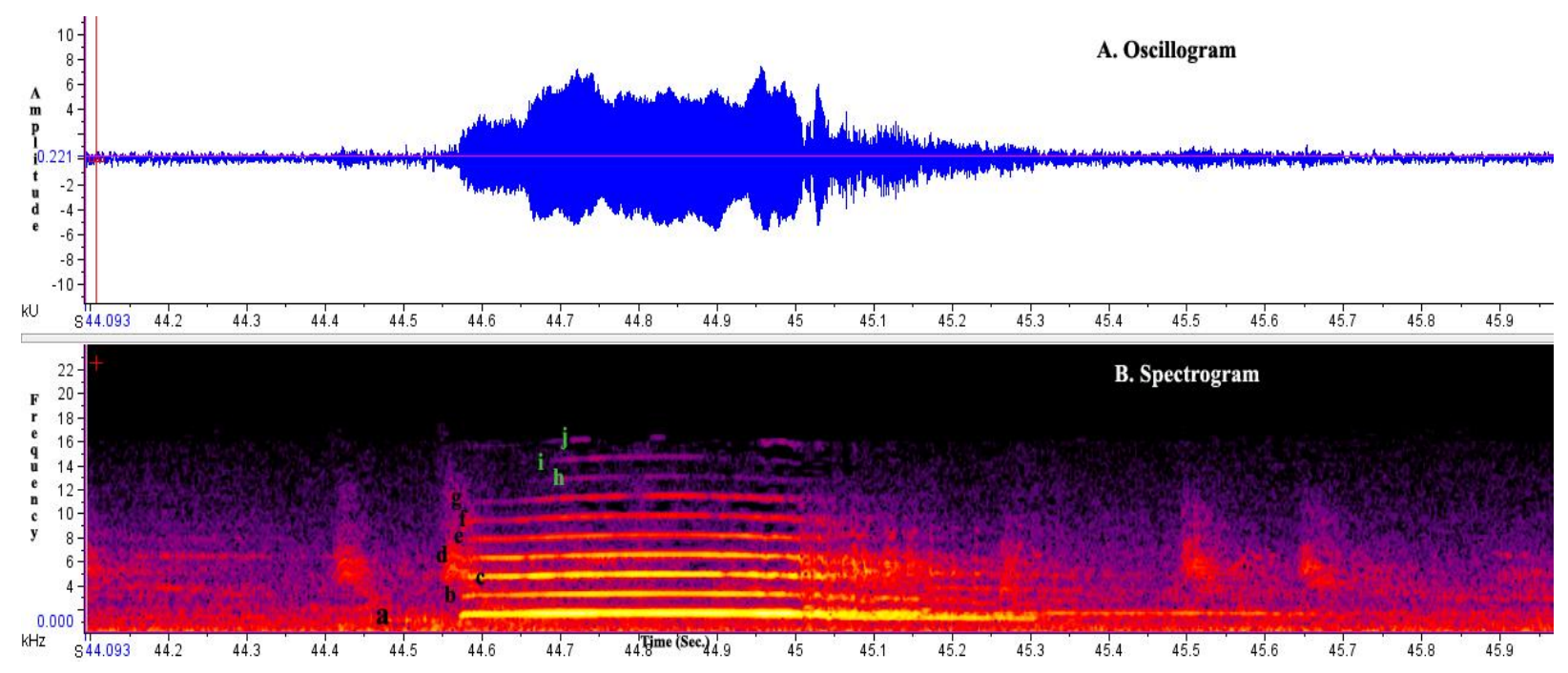

Figure 2: Oscillogram and Spectrogram of one call. 